\title{
Kesuksesan Komisi Pemilihan Umum dalam Menyelenggarakan Pemilu 2019
}

\section{The success of the General Election Commission in Holding of 2019 Election}

\author{
Paul Adryani Moento \\ Universitas Musamus \\ Jl. Kamizaun Mopah Lama, Rimba Jaya, Kec. Merauke, Kabupaten Merauke, Papua \\ 99611 \\ *corresponding author E-mail: paulmoento@unmus.ac.id
}

Diterima: 7 Maret 2020; Direvisi: 29 Maret 2020; Disetujui: 30 Maret 2020

\begin{abstract}
ABSTRAK
Komisi Pemilihan Umum (KPU) adalah lembaga penyelenggara Pemilihan Umum yang bersifat nasional, tetap, dan mandiri. Tujuan penelitian ini untuk mengetahui kesuksesan KPU dalam menyelenggarakan Pemilu 2019. Metode penelitian yang digunakan dalam penelitian ini ialah Studi Pustaka dan Studi Lapangan dengan teknik wawancara dan tanya jawab. Hasil penelitian menunjukkan bahwa kesuksesan Komisi Pemilihan Umum tidak luput dari partisipasi masyarakat. Kemudian, Komisi Pemilihan Umum Kabupaten Merauke juga melakukan sosialisasi dan bekerjasama dengan organisasiorganisasi yang ada di Kabupaten Merauke. Kerjasama tersebut bertujuan untuk membantu menyukseskan Pemilu 2019 di Kabupaten Merauke. Kerjasama tersebut juga berupa penejelasan tentang bagaimana menjadi pemilih yang baik. Dalam mensukseskan Pemilu 2019, Komisi Pemilihan Umum Kabupaten Merauke juga melakukan kerjasama dengan pihak Bawaslu, Aparat Pemerintahan, LSM, \& Unsur-unsur Pendidikan.
\end{abstract}

Kata kunci: Kesuksesan, KPU, Pemilu

\section{ABSTRACT}

The General Election Commission (KPU) is a national, permanent, and independent Election Organizer body tasked with carrying out the General Elections. The aims of this study is to determine the success of the KPU in holding the 2019 Election. The research method used in this research is the Literature Study and Field Study with interview and question and answer techniques. The results showed that the success of the General Election Commission did not escape from community participation. Then, the Merauke the General Election Commission also conducts socialization and cooperates with organizations in Merauke District. The cooperation aims to help the success of the 2019 elections in Merauke District. The cooperation also takes the form of an explanation of how to become a good voter. In the success of the 2019 Elections, the Merauke

POLITICON VOL.2 No.1 Maret 2020 
POLITICON : Jurnal Ilmu Politik Vol.2 No.1; Hal.35 - 47

Website : http://journal.uinsgd.ac.id/index.php/politicon

ISSN : 2685-6670 ( Online )

General Election Commission also cooperated with the Bawaslu, Government Officials, NGOs, and Educational Elements.

Keywords: Election, KPU, Success,

\section{PENDAHULUAN}

Komisi Pemilihan Umum saat ini merupakan lembaga penyelenggara Pemilu keempat yang dibuat setelah pemilu Demokratis tahun 1955. Tahapan pembentukan KPU pertama pada tahun 1999-2001 yang dibentuk dengan Keppres No. 16 tahun. Tujuannya untuk memperoleh kekuasaan politik dan memperebut kedudukan politik, biasanya dengan cara konstitusional untuk melaksanakan kebijaksanaannya mereka (Pasaribu, 2017). KPU kedua pada tahun 2001-2007 dibentuk dengan Keppres No 10 tahun 200. KPU ketiga pada tahun 2007-2012 dibentuk berdasarkan Keppres No 101/p/2007. Ada juga Tugas, Wewenang, dan Kewajiban KPU Pasal 10 Ayat 1 dalam penyelenggaraan Pemilu tersebut yaitu, KPU mempunya tugas: membuat anggran, membuat jadwal Jadwal perencanaan anggaran, pembentukan tata kerja Komisi pemilihan umum, komisi pemilihan umum provinsi, komisi pemilihan umum kabupaten/kota, PPK, KPPS, KPPSLN, PPS dan membuat aturan-aturan pada setiap tahapan pemilu, ditambah dengan menyelenggarakan, memantau dan mengendalikan semua tahapan pemilu.

Pemilukada di adakan untuk memilih kepala daerah yang berkualitas dan bertanggung jawab, menciptakan stabilitas politik serta dengan menganut sistem terbuka ada harpan untuk mendapatkan pimpinan nasional yang berkualitas. (ICMI TRI HANDAYANI, 2014). Adapun Perannya yaitu, membangun institusi demokrasi yang kuat dan andal. Dengan demikian, tiga pilar KPU, yaitu Independensi Struktural, Independensi Fungsional, dan Independensi Pribadi, harus secara konsisten dan dipertahankan (Marzuki, 2008).

Setelah Perang Dunia Ke II usai, sistem demokrasi dengan cara pemilihan umum sudah banyak dilakukan oleh negara - negara. Pemilu selain untuk pemilihan kepala daerah juga merupakan cara untuk mengekpresikan 
kebebasan berpendapat bagi masyarakat dalam memilih pemimpin, dan juga dapat berguna sebagai wadah penilaian langsung oleh masyarakat terhadapat pemimpin, yaitu, dengen memberikan kembali suaranya apabila pemimpin tersebut benar - benar berkualitas. Pada titik ini pemilu sudah menjadi suatu gagasan mengenai demokrasi dan kedaulatan rakyat (Arrsa, 2014).

Dari tahun 1955, negara ini sudah menyelenggarakan 11 Pemilu. Memberikan hak kepada rakyat untuk menentukan kekuasaannya dalam Undang-Undang Nomor 22 tahun 2007 tentang penyelenggara Pemilu hal tersebut berdasarkan UUD 1945 Pasal 1 Ayat 3, Keanggotaan KPU komposisinya harus memperhatikan keterwakilan perempuan sekurangkurangnya 30\% (tiga puluh persen) dan masa keanggotaan KPU 5 (lima) tahun.

Penyelenggara pemilu berpedoman kepada asas : Mandiri, Jujur, Adil, Kepastian Hukum, Tertib Penyelenggara Pemilu, Kepentingan Umum, dan Keterbukaan. Jadi dalam penyelenggaraan Pemilu KPU harus mengikuti peraturan yang telah ditetapkan oleh pemerintah agar keterlibatan perempuan dalam pemilihan umum sudah terwakili dan untuk dalam pemilihan sosok pemimpin merupakan suatu peristiwa besar yang sangat krusial bagi setiap negara maupun daerah masing-masing. Oleh karena itu, haruslah diikuti dengan tingkat partisipasi masyarakat yang tinggi dan memilih secara rasional sebagai suatu karya untuk memberikan yang terbaik bagi negara (Novianty \& Octavia, 2018).

Mekanisme demokrasi untuk memilih seseorang yang akan mewakili rakyat dan untuk memimpin itu adalah pengertian Pemilu secara luas (Geraldy, 2019). Di Indonesia istilah demokrasi dalam UUD 1945 pada Pasal 33 ayat 4 yang mengatur tentang perekonomian nasional yang kemudian diselenggarakan berdasar atas ekonomi. Hal ini dapat ditafsirkan bahwa kegiatan perekonomian bangsa dan negara harus ditujukan kepada kepentingan rakyat atau secara ekonomi rakyatlah yang berdaulat. Atau meminjam istilah Murbyarto, Guru Besar ekonomi Universitas Gajah Mada, 
adalah ekonomi rakyat1, yang kini di masa musim kampanye diusung oleh salah satu kandidat Presiden dan partai tertentu sebagai program kampanyenya. Adapun ciri sebuah negara demokratis adalah seberapa besar negara melibatkan masyarakat dalam perencanaan atau pelaksanaan pemilihan umum. Sebab partisipasi politik masyarakat merupakan aspek penting dalam sebuah tatanan negara yang berdemokrasi (Liando, 2016).

Ada juga etika dalam lembaga penyelenggara pemulu yang harus dipatuhi. Etika tersebut merupakan hal - hal penting yang harus diikuti oleh setiap instansi yang bertanggung jawab terhadapat penyelenggaraan pemilu agar tercapainya pemilu yang demokratis (Chakim, 2014).

KPU Provinsi adalah lembaga penyelenggara pemilihan umum yang ada pada lini tengah menjembatani dua penyelenggara pemilu yaitu KPU di tingkat Pusat dan KPU Kabupaten atau Kota. KPU Provinsi ada untuk memberi suatu peran dan tanggung jawab yang sangat strategis untuk KPU Provinsi dalam pelaksanaan tugasnya, sehingga fungsi koordinasinya dan hubungan kerja sangat diperlukan dalam pengelolaan tugas dan fungsi selaku penyelenggara Pemilihan Umum (Achyani, Gana, \& Kase, 2015). Dalam melaksanakan Pemilu 2019 ini yaitu KPU Kabupaten/Kota bertugas menjabarkan program dan melaksanakan anggaran, menetapkan dan mengumumkan rekapitulasi hasil penghitungan suara Pemilu Anggota DPRD Kabupaten/Kota, dan menyampaikan daftar pemilih kepada KPU Provinsi.

Pemilu 2019 ialah pemilihan yang diselenggarakan secara serentak, dengan tujuan untuk memilih anggota eksekutif yaitu Presiden dfan Wakil Presiden, Anggota Legistalif yaitu (DPR-RI, DPD, DPR-Provinsi, DPR Kabupaten). Pemilu tersebut dilakukan sesuai putusan yang dikeluarkan oleh Mahkamah Konstitusi Nomor 14/puu-ii/2013 tentang Pemilu Serentak dengan tujuan meminimalkan pembiayaan negara dalam pelaksanaan pemilu, biaya politik peserta pemilu serta diharapkan dapat mengurangi politik uang dalam penyelengaraannya. Ada juga penilaian yang baik pada penyelenggara Pemilu, baik KPU, Bawaslu, hingga aparat keamanan atas suksesnya Pemilu 
POLITICON : Jurnal Ilmu Politik Vol.2 No.1; Hal.35 - 47

Website : http://journal.uinsgd.ac.id/index.php/politicon

ISSN : 2685-6670 ( Online )

2019 dari Bapak Bupati Kabupaten Merauke.

Kami juga menambahkan kesuksesan pelaksanaan Pemilu 2019 oleh KPU, yaitu pemilu tersebut telah dilaksanakan secara aman dan lancar tanpa Pungutan Suara Ulang atau PSU. Ini tak terlepas dari semua penyelenggara baik KPU, PPD, PPS, Hingga KPPS. Untuk itu, atas nama Ketua KPU Merauke, beliau mengucapkan terima kasih kepada para penyelenggara, baik KPPD di 20 distrik, PPS, serta KPPS di 179 kampung serta 11 kelurahan, dan 7000-an penyelenggara yang dilakukan secara jujur dan adil.

Keberhasilan tersebut karena banyaknya upaya yang dilakukan oleh KPU untuk mensukseskan Pemilu 2019. Salah satunya dengan cara sosialisasi politik. Menurut Joko J. Prihatmoko (2003) sosialisasi politik merupakan bentuk dari tumbuhnya kepribadian politik dan kesadaran politik dan paritisipasi masyarakat, untuk itu peningkatan pendidikan politik sangat diperlukan bagi menumbuhkan budaya demokratis (Putri, 2015).

Ada sosialisasi politik yang juga dilakukan KPU Merauke dengan target sasaran para pemilih pemula, disabilitas, dan kaum perempuan. Sosialisasi yang dilakukan mulai dimaksimalkan sejak pertengahan bulan Februari 2019 hingga tanggal pelaksanaan Pemilu 2019. Sosialisasi dilaksanakan dengan cara memberi informasi kepada masyarakat tentang bagaimana cara menghemat waktu di TPS dan cara mencoblos dengan baik dan benar, serta membedakan masing-masing kertas suara yang sesuai peruntukkannya. Sosialisasi ini sangat penting dilakukan dalam rangka mengecilkan presentase golput. Hal ini disebabkan intensitas Pemilu di Indonesia lumayan tinggi dalam setiap pemilu di Negara Indonesia (Cahyo, 2015).

Keberhasilan KPU Merauke pada Pemilu 2019 tersebut tentunya tidak luput dari kendala-kendala ataupun permasalahan yang terjadi di lapangan misalnya masih adanya masyarakat yang tidak terdaftar sebagai DPT, masyarakat yang tidak bisa menggunakan hak suaranya karena kehabisan surat suara di TPS terdekat. Berdasarkan paragraf sebelumnya kita dapat mengetahui alasan suksesnya KPU dan masalah yang di hadapi dalam 
menyelenggarakan pemilu 2019. Tujuan Penelitian ini untuk mengkaji strategi apa yang di terapkan KPU dalam menyelenggarakan pemilu 2019 di kabupaten merauke.

\section{METODE PENELITIAN}

Untuk mendapatkan gambaran dan penjelasan yang terperinci atas kesuksesan KPU dalam menyelenggarakan Pemilu di Kabupaten Merauke, penyusun menggunakan metode studi pustaka. Yaitu, mengumpulkan datadata yang diperlukan dengan cara dibaca, dicatat, dikutip, kemudian dipahami sesuai dengan referensi yang berkaitan dengan isi artikel. Selain itu, ada juga melalui studi lapangan, yaitu, melalui salah satu bentuk pembelajaran outdoor di mana terjadi kegiatan observasi untuk mengungkap fakta-fakta guna memperoleh data dengan cara terjun langsung ke lapangan. Demikian juga, penelitian ini berjalan dengan pengumpulan data melalui wawancara dengan pokok masalah yang akan diteliti. Selanjutnya, proses analisis data penelitian di lakukan dengan tahap: reduksi data, penyajian data, serta melakukan pengambilan sebuah kesimpulan (J.Moleong, 2015).

\section{TEMUAN DAN PEMBAHASAN}

Menurut hasil penelitian, dalam mewujudkan Pemilu 2019 yang baik (Warjiyati, 2020), terdapat tantangan dan peluang yang dilihat dari pandangan politik, baik itu dari sisi parpol, pemerintah, pemilih, maupun penyelenggara pemilihan umum. Oleh karena itu, dibutuhkan suatu strategi untuk membuat suatu pemilihan serentak dalam pandangan politik, yaitu, bisa melalui sistem perwakilan, sistem partai, sistem pemilih, dan tujuan yang harus ditekankan dalam penyelenggaran Pemilu Serentak, yaitu menciptakan suatu pemeintahan yang baik (Solihah, 2018).

\section{TEORI SPLIT-TICKET VOTING}

Salah satu teori yang penyusun gunakan adalah teori Split-Ticket Voting yang sudah ada sejak 1960-an dan 1970-an. Split Ticket Voting adalah penjelasan tentang fenomena yang lahir akibat adanya bermacam pemilihan, seperti misalnya pemilihan legislatif (DPR) dan pemilihan eksekutif 
POLITICON : Jurnal Ilmu Politik Vol.2 No.1; Hal.35 - 47

Website : http://journal.uinsgd.ac.id/index.php/politicon

ISSN : 2685-6670 ( Online )

(Presiden). Split ticket voting juga merupakan sebutan untuk pemilih yang memilih calon berbeda pada beberapa jenis pemilihan. Contohnya, pada pemilu legislatif memilih calon dari Partai Nasdem, sedangkan pada Pemilihan Presiden memilih pasangan calon yang diusung oleh Partai PDIP. Di sini pemilih membagi suara (Split) untuk bermacam partai pada beberapa jenis pemilihan. Fenomena Split-Ticket Voting ini kerap terjadi di Pemilu Indonesia pasca Orde Baru. Ada beberapa cara untuk menjelaskan Split-Ticket Voting. Pertama, Teori Keseimbangan dari Heider adalah mengenai hubunganhubungan antar pribadi (Denontarr, 2008). Teori Keseimabangan atau Check And Balance merupakan suatu mekanisme yang menjadi tolok ukur kemapanan konsep negara hukum dalam rangka mewujudkan demokrasi (Adi, 2015).

Mengacu pada Teori Split Ticket Voting, dan data hasil penelitian yang penyusun temukan di lapangan bahwasanya teori ini sangat berhubungan karena sesuai dengan data yang penyusun dapat pada Rapat Pleno Terbuka Penetapan Anggota Terpilih DPRD Merauke Periode 2019-2024. Rapat Pleno yang dibuka langsung oleh Ketua KPU Merauke Theresia Mahuze menetapkan 30 calon legislatif terpilih dari 9 partai pada 5 daerah pemilihan. PKB dan Partai Nasdem mendapatkan 5 kursi pada masing-masing partai, Partai Golkar, Partai Keadilan Sejahtera dan PDIP mendapatkan 4 kursi serta 3 kursi, sedangkan untuk Partai Gerindra, Hanura, dan PPP masing-masing 2 kursi, dan Partai Demokat 1 kursi.

Dengan penetapan caleg terpilih maka secara sah DPRD Merauke periode 2019-2024 diduduki mayoritas oleh Non Papua, ytakni berjumlah 25 kursi atau 25 orang, sedangkan posisi minirotas ditempati Orang Asli Papua berjumlah 5 kursi atau orang.

Dari hasil temuan di atas penyusun berpendapat bahwa Teori SplitTicket Voting sesuai dengan hasil Pemilu 2019 di Kabuapaten Merauke. Hal itu ditujukkan dengan calegnya yang terpilih sebanyak 30 orang yang berasal dari beberapa partai, yaitu, Partai Persatuan Pembangunan, Partai Demokrat, 
POLITICON : Jurnal Ilmu Politik Vol.2 No.1; Hal.35 - 47

Website : http://journal.uinsgd.ac.id/index.php/politicon

ISSN : 2685-6670 ( Online )

Partai Kebangkitan Bangsa, Partai Nasdem Partai Golkar, PKS dan PDI-P, Partai Gerindra, dan Partai Hanura.

\section{PERIHAL PEMILU}

Pemilu menurut Suryo Untoro adalah hak yang diberikan kepada masyarakat untuk memilih pemimpin beserta wakil-wakilnya, baik yang duduk dilembaga ekskutif maupun legislatif (Nazir, 2017). Dari pemaparan itu dapat dibuat kesimpulan bahwa pemilihan umum secara luas merupkan suatu sara yang penting bagi kehidupan negara yang berpedoman pada demokrasi dengan memberikan kesempatan secara luas kepada masyarakat untuk berpartisipasi melalu suaranya.

Kemudian kaitan hasil studi lapangan dengan Teori Pemilu yang diutarakan oleh Suryo Untoro sangatlah berkaitan. Karena menurut hasil studi lapangan yang penyusun lakukan bahwasanya dalam Pemilu 2019 merupakan ajang masyarakat Republik Indonesia yang telah terdaftar sebagai DPT atau Daftar Pemilih Tetap oleh KPU untuk menentukan hak pilih mereka dalam pemilihan wakil rakyat yang duduk di kursi DPR, DPRD Provinsi, DPRD Kabupaten/Kota. Selain itu Pemilu 2019 lalu merupakan Pemilu Serentak pertama yang dilakukan di Indonesia dan pertama juga di Dunia. Yaitu, pelaksanaan pemilihan anggota legislatif dan juga exsekutif secara bersamaan.

Pemilu Presiden merupakan masalah pertama pondasi awal suatu demokrasi, sebagai sarana dan peristiwa yang baik bagi masyarakat untuk dapat memilih calon-calon pimpinan yang nantinya akan merubah daerah maupun negara menjadi lebih baik lagi(R Siti Zuhro, 2019). Hal tersebut berkaitan dengan Pemilu 2019 yang ada di Merauke. Partisipasi masyaraakat untuk menyalurkan aspirasi politiknya dengan cara memilih calon presiden dan wakil presiden serta calon anggota legislatif meningkat dari tahun sebelumnya, yaitu 76,34\% .

\section{STRATEGI KPU MERAUKE}

KPU disebut sebagai lembaga independen sebagaimana termaktub dalam UU No. 7 tahun 2017 tentang Pemilihan Umum. Dengan predikat 
tersebut KPU tahun 2019 dinilai sukses dalam penyelenggaraan karena dari mulai perencanaan hingga tahap pelaksanaan KPU mengikuti aturan yang telah ditetapkan oleh pemerintah dan tidak keluar dari jalur ataupun koridor yang ada. KPU menyelenggarakan tugas sesuai tingkat atau tahapan-tahapan Pemilu sebagai mana dalam Praturan KPU No. 5 tahun 2015.

Adapun pembagian tugas yang didalakukan oleh KPU Merauke itu sendiri dibagi menjadi beberapa Divisi yang memiliki tugas dan fungsi yang berbeda beda. Atara lain: Divisi Sosialisasi, Divisi Perencanaan data dan informasi, Divisi Teknis Penyelanggara, Divisi Hukum, dan Divisi Keuangan Logistik.

Dari semua divisi tersebut, dari mulai persiapan yang dilakukan hingga perencanaan dengan anggaran semua berlandaskan Peratuan KPU No. 5 Tahun 2015, berkat hasil kinerja yang sangat sangat baik. KPU Merauke mendapatkan apresiasi sebagai salah satu KPU yang sukses melaksanakan kegiatan Pemilu Serentak di tingkat daerah (Papua) hal ini tentunya sangatlah menjadi sebuah prestasi baik bagi KPU dan warga masyarakat Merauke yang turut berpartisipasi dalam mensukseskan kegiatan ini. Selain itu, keberhasilan KPU pada Pemilu 2019 dikarenakan jumlah partisipan pada Pemilu Serentak tahun itu mengalami kenaikan yang cukup signifikan dibandingkan tahun sebelumnya. Adapun data yang penyusun dapatkan ialah tingkat partisipasi masyarakat di Pemilu 2019 di Kabupaten Merauke pada tahun 2018 adalah 61,84\% dan pada tahun 2019 menjadi 76,34 \% .

Di samping itu, aturan yang digunakan dalam Pemilu 2019, yaitu Peraturan Kpu Nomor 15 Tahun 2019 tentang Tahapan, Jadwal, Program di Pelaksanaan Pemilu. Adapun tahapan-tahapan yang ada adalah sebagai berikut: Persiapan, Perencanaan, Sosialisasi, Penyelenggaraan. Hal itu senada juga dari pendapat Berger, dia menyatakan bahwa proses sosialisasi dalam politik dengan seseorang belajar menjadi anggota masyarakat yang baik dalam proses politik, sosialisasi politik menjadi hal penting yang tidak boleh dilewatkan pada setiap acara-acara pemerintahan karena proses inilah yang 
POLITICON : Jurnal Ilmu Politik Vol.2 No.1; Hal.35 - 47

Website : http://journal.uinsgd.ac.id/index.php/politicon

ISSN : 2685-6670 ( Online )

nantinya dapat meningkatkan partisipasi masyarakat dalam proses politik(Djuyandi, 2014).

Tentunya dari kesuksesan KPU tersebut didukung juga oleh beberapa lembaga lain yang bekerja sama dengan badan pengawas pemilu dan juga dewan kode etik karena 3 lembaga tersebut merupakan Lembaga-lembaga penyelenggara Pemilu, Selain itu. langkah lain yang dilakukan oleh KPU dalam meningkatkan partisipasi pemilih pada pemilu serentak 2019 adalah dengan melakukan sosialisasi terus menerus yang berfokus pada beberapa basis kalangan, seperti masyarakat marjinal, pemuda, disabilitas. Khususnya lagi, kelompok masyarakat pemilih pemula.

Selain itu, untuk meningkatkan partipasi dari masyarakat dan mengatasi adanya Golongan Putih atau Golput, KPU Merauke menerapkan strategi nasional dalam Pemilu 2019, membuat pelaksanaan Pemilu pada 17 April lalu menjadi semenarik mungkin dengan mengadakan beberapa lomba seperti kegiatan lomba Tarian Yospan, Panggung Konser Music, Lomba Selfi di TPS, dan Video Pendek.

Langkah lain yang juga dilakukan oleh KPU adalah mengundang dan berdiskusi langsung dengan Ketua-Ketua Organisasi Mahasiswa, seperti HMI, GMKI, dan KAMMI.

Tugas KPU yang paling berat dalam pemilu 2019, yaitu membangun pendidikan politik kepada masyarakat dan hak-hak mereka, untuk menyukseskan masyarakat karena masyarakat harus tahu. Tentunya dalam kesuksesan yang berhasil diraih oleh KPU Merauke terdapat beberapa kendala. Namun hal tersebut tidak menjadi masalah yang berarti berkat kerja keras dari KPU, Bawaslu, masyarakat serta aparat yang bertugas. Adapun masalah yang ada dalam Pemilu 2019, yaitu, banyak masyarkat yang terdaftar tapi tidak ikut memilih, masalah administrasi seperti kelengkapan pemilu yang kurang, masyarakat belum memahami betul tentang bagaimana menyalurkan suara. Namun masalah tersebut dapat diatasi karena KPU telah memiliki sistem yang cukup canggih. Adapun sistem yang digunakan KPU 
tersebut adalah SIDALIH (Sistem Informasih Data Pemilih). Menggunakan SIDALIH agar dapat menemukan kesalahan seperti data ganda, KTP, KK, nama yang salah untuk meminimalisir terjadinya kecurangan dan lain-lain.

Jadi total Daftar Pemilih Tetap pada Pemilu 2019 adalah 148,526 orang, yang kedepannya diprediksi akan terus meningkat pada pemilu daerah yang akan dilaksanakan pada bulan September tahun 2020. Selain itu, dalam upaya KPU untuk terus mengedukasi masyarakat mengenai pengenalan politik, KPU terus berinovasi dengan membentuk Rumah Pintar Pemilu (RPP) yang kapan saja bisa dikunjungi masyarakat agar mendapatkan pengetahuan mengenai ilmu politik.

\section{SIMPULAN}

Kesuksesan KPU dalam pemilu 2019, yaitu, dengan cara meningkatkan partisipasi politik dari masyarakat, KPU menerapkan strategi nasional dalam Pemilu 2019, seperti membuat pelaksanaan Pemilu pada 17 April lalu menjadi semenarik mungkin dengan mengadakan beberapa lomba seperti Kegiatan Lomba Tarian Yospan, Panggung Konser Music, Lomba Selfi di TPS, dan Video Pendek. Langkah lain yang juga dilakukan oleh KPU adalah mengundang dan berdiskusi langsung dengan Ketua-Ketua Organisasi mahasiswa, seperti HMI, GMKI, dan KAMMI.

Tentunya kesuksesan KPU tersebut didukung juga oleh beberapa lembaga lain yang bekerjasama dengan Badan Pengawas dan juga Dewan Kode Etik karena 3 lembaga tersebut merupakan lembaga-lembaga penyelenggara Pemilu. Selain itu langkah lain yang dilakukan oleh KPU dalam meningkatkan partisipasi pemilih pada Pemilu serentak 2019 adalah dengan melakukan sosialisasi terus menerus yang berfokus pada beberapa basis kalangan, seperti masyarakat marjinal, pemuda, disabilitas, pemilih pemula.

\section{DAFTAR PUSTAKA}

Achyani, F. T., Gana, F., \& Kase, P. (2015). Efektivitas Hubungan Kerja Komisioner dengan Sekretariat Komisi Pemilihan Umum Provinsi Nusa Tenggara Timur. JKAP (Jurnal Kebijakan Dan Administrasi Publik). 
POLITICON : Jurnal Ilmu Politik Vol.2 No.1; Hal.35 - 47

Website : http://journal.uinsgd.ac.id/index.php/politicon

ISSN : 2685-6670 ( Online )

https://doi.org/10.22146/jkap.7533

Adi, A. A. (2015). Trias Politica dan Checks and Balances a la Indonesia.

Arrsa, R. (2014). Pemilu Serentak Dan Masa Depan Konsolidasi Demokrasi. Jurnal Konstitusi.

Cahyo, M. B. D. (2015). Tingkat Partisipasi Masyarakat dalam Menggunakan Hak Suara pada Pemilu Legislatif 2014. Pandecta: Research Law Journal. https://doi.org/10.15294/pandecta.v10i1.4197

Chakim, M. (2014). Desain Institusional Dewan Kehormatan Penyelenggara Pemilu (DKPP) Sebagai Peradilan Etik. Jurnal Konstitusi. https://doi.org/10.31078/jk

Denontarr. (2008). Teori Keseimbangan Menurut Heider.

Djuyandi, Y. (2014). Efektivitas Sosialisasi Politik Pemilihan Umum Legislatif

Tahun 2014 oleh Komisi Pemilihan Umum. Humaniora, 5(2), 1202. https://doi.org/10.21512/humaniora.v5i2.3263

Geraldy, G. (2019). Ideologi dan Partai Politik: Menakar Ideologi Politik Marhaenisme di PDIP, Sosialisme Demokrasi di PSI dan Islam Fundamentalisme di PKS. Politicon: Jurnal Ilmu Politik, 1(2), 134-157.

ICMI TRI HANDAYANI. (2014). Tinjauan Yuridis Terhadap Kampanye Pemilihan Umum Kepala Daerah Dalam Penggunaan Media Televisi Sebagai Media Kampanye.

J.Moleong, L. (2015). Metodelogi Penelitian Kualitatif. Bandung: PT Remaja Rosdakarya Bandung.

Liando, D. M. (2016). Pemilu Dan Partisipasi Politik Masyarakat ( Studi Pada Pemilihan Anggota Legislatif Dan Pemilihan Presiden Dan Calon Wakil Presiden Di Kabupaten Minahasa Tahun 2014 ). Jurnal LPPM Bidang EkoSosBudKum.

Marzuki, S. (2008). Peran Komisi Pemilihan Umum Dan Pengawas Pemilu Untuk Pemilu Yang Demokratis. Jurnal Hukum Ius Quia Iustum. https://doi.org/10.20885/iustum.vol15.iss3.art8

Nazir, A. (2017). Pengaruh Tata Kelola Pemilih Terhadap Efektivitas. Jurnal 
POLITICON : Jurnal Ilmu Politik Vol.2 No.1; Hal.35 - 47

Website : http://journal.uinsgd.ac.id/index.php/politicon ISSN : 2685-6670 ( Online )

Ilmiah Prodi Manajemen Universitas Pamulang, Vol. 4, No, 82-97.

Novianty, F., \& Octavia, E. (2018). Peran Komisi Pemilihan Umum (KPU) dalam

Menumbuhkan Partisipasi Politik bagi Pemilih Pemula di Kecamatan

Pontianak Barat. Sosial Horizon: Jurnal Pendidikan Sosial. https://doi.org/10.31571/sosial.v5i2.989

Pasaribu, P. (2017). Peranan Partai Politik dalam Melaksanakan Pendidikan

Politik. JPPUMA: Jurnal Ilmu Pemerintahan Dan Sosial Politik Universitas Medan Area. https://doi.org/10.31289/jppuma.v5i1.1125

Putri, M. P. (2015). Peran Komisi Pemilihan Umum Dalam Sosialisasi Pemilu sebagai upaya Untuk Meningkatkan Partisipasi Politik Masyarakat Pada Pemilu Presiden 2014 di. Ejournal.Ilkom.Fisip-Unmul.Ac.Id.

R Siti Zuhro. (2019). Demokrasi Dan Pemilu Presiden 2019. Jurnal Penelitian Politik, Volume 16, 69-110.

Solihah, R. (2018). Peluang dan tantangan pemilu serentak 2019 dalam perspektif politik. Jurnal Ilmiah Ilmu Pemerintahan, 3(1), 73. https://doi.org/10.14710/jiip.v3i1.3234

Warjiyati, S. (2020). Penataan Struktur dan Kewenangan Komisi Pemilihan Umum, Badan Pengawas Pemilu dan Dewan Kehormatan Penyelenggara Pemilu dalam Upaya Mewujudkan Pemilihan Umum yang Demokratis di Indonesia. ARISTO, 8(1), 24-37. 